Research Article

\title{
Semisolid Compression Brazing of Al50Si Alloy Using Zn-Al-Cu Filler Metal Assisted by SiC Particles
}

\author{
Jing Xiao $\mathbb{D}^{D}$, Shun Li $\left(\mathbb{D}\right.$, Shuxin Bai $\left(\mathbb{D}\right.$, Degan Xiong ${ }^{(D)}$, and Yu Tang \\ College of Aerospace Science and Engineering, National University of Defense Technology, Changsha 410073, China \\ Correspondence should be addressed to Shun Li; linudt@163.com and Shuxin Bai; 13272093806@163.com
}

Received 27 September 2019; Revised 20 November 2019; Accepted 26 November 2019; Published 18 December 2019

Academic Editor: Pasquale Gallo

Copyright (c) 2019 Jing Xiao et al. This is an open access article distributed under the Creative Commons Attribution License, which permits unrestricted use, distribution, and reproduction in any medium, provided the original work is properly cited.

\begin{abstract}
Semisolid compression brazing of Al50Si alloy using $\mathrm{Zn}-\mathrm{Al}-\mathrm{Cu}$ filler metal assisted by SiC particles coating has been developed. The effects of the size and concentration of SiC particles on the microstructure and mechanical properties of the joints were studied. By using $1 \mu \mathrm{m} \mathrm{SiC} \mathrm{particles} \mathrm{and} \mathrm{the} \mathrm{concentration} \mathrm{of} \mathrm{SiC}$ particles increased to $3 \mathrm{~g} / \mathrm{m}^{2}$, oxide film on the surface of base metal was completely disrupted and a good bonding strength was obtained. As SiC concentration further increased to $4 \mathrm{~g} / \mathrm{m}^{2}$, colonies of $\mathrm{SiC}$ particle with nonwetting areas of filler metal formed at the interface, resulting in a decrease in the bonding strength. By using $5 \mu \mathrm{m} \mathrm{SiC}$ particles, the bonding strength was enhanced as $\mathrm{SiC}$ concentration increased from $1 \mathrm{~g} / \mathrm{m}^{2}$ to $3 \mathrm{~g} / \mathrm{m}^{2}$ due to the removal of the oxide film. By further increasing $\mathrm{SiC}$ concentration to $16 \mathrm{~g} / \mathrm{m}^{2}$, the strength was constantly improved because of the dislocation strengthening effect generated at the SiC particle layer/filler metal interface. When SiC concentration increased to $32 \mathrm{~g} / \mathrm{m}^{2}$, nonwetting area appeared inside the $\mathrm{SiC}$ particles layer, causing a decrease in the bonding strength.
\end{abstract}

\section{Introduction}

Al50Si alloys with high thermal conductivity and low expansion have high potential in electronic packaging fields. The associated joining technologies for these materials have been increasingly investigated. Ideally, brazing is a fast, reliable joining technology for aluminum alloys. However, the oxide film on substrate surface is one of the major barriers in achieving reliable joints. Removal of the oxide film is usually necessary before brazing aluminum alloys. Previous brazing approaches require vacuum environment or flux to remove the oxides, adding the cost and also impacting the environment. Flux-less brazing methods, such as removing the oxide film via pretreatments of magnetron sputtering [1], electroless plating [2], and ultrasonic cladding [3], have limited application because of the sophisticated equipment and/or extreme conditions before bonding.

Mechanical energy-assisted semisolid brazing is a promising method that has the potential to overcome the oxide problem. The compression and friction of the solid grains in the filler metal can result in fragmentation of the surface oxide layers under the mechanical energies, and therefore, bond strengths can be improved dramatically [4-8]. However, these methods are of limited use for aluminum alloys due to the presence of more continuous surface oxide films on such alloys. To overcome this difficulty, application of high mechanical energies is required (e.g., bonding pressure, vibration frequency, and stirring rate), which causes a substantial deformation or destruction to the base metal.

A new method for soldering of aluminum alloys using a low-melting-point filler metal assisted by ceramic particles has been recently developed [9]. The key feature of this new method is that the surface oxide film was successfully destroyed by mechanical abrasion of ceramic particles applied to the aluminum surface under the ultrasonic vibration condition. Moreover, since ceramic particles with high melting points exhibit high stiffness and excellent wear resistance, vibration energy required is reduced and damage to base metal is avoided during the bonding process.

Hence, a semisolid compression brazing of Al50Si alloy using $\mathrm{Zn}$-Al-Cu filler metal assisted by $\mathrm{SiC}$ particles has been developed in this paper. $\mathrm{SiC}$ particles were applied to the aluminum surface to disrupt the surface oxide film under 
pressure together with solid grains in the filler metal. The effects of the size and concentration of $\mathrm{SiC}$ particles on the microstructure and mechanical properties of the joints were studied.

\section{Materials and Methods}

Spraying deposition Al50Si alloys with dimensions of $30 \times 30 \times 3 \mathrm{~mm}$ were used as the base metals. As-rolled $\mathrm{Zn}$ $12 \mathrm{Al}-4.5 \mathrm{Cu}$ alloys with dimensions of $30 \times 30 \times 0.3 \mathrm{~mm}$ were used as the filler metals. The solidus temperature and liquidus temperature of the filler metal were $375^{\circ} \mathrm{C}$ and $410^{\circ} \mathrm{C}$, respectively. All samples to be bonded were mechanically polished to a 600-grit finish and ultrasonically degreased in acetone for $10 \mathrm{~min}$ before joining.

The semisolid brazing process is a two-step process consisting of surface presprinkling step and a subsequent joining step. In the former step, suspensions of $\mathrm{SiC}$ particles in ethanol were prepared by ultrasonic mixing in a $50 \mathrm{~mm}$ diameter cylindrical beaker for $10 \mathrm{~min}$, as shown in Figure 1(a). The ultrasonic frequency was $20 \mathrm{kHz}$, and the power was $500 \mathrm{~W}$. SiC particles with two different sizes, $1 \mu \mathrm{m}$ and $5 \mu \mathrm{m}$, were used, respectively. As soon as the ultrasonic mixing was stopped, Al50Si alloys were quenched in the suspensions and kept still to allow $\mathrm{SiC}$ particles to sediment. Afterwards, ethanol on the upper layer of the beaker was sucked out by using a pipette, and the left over in the bottom of the beaker was removed by heating to obtain Al50Si alloy sprinkled with $\mathrm{SiC}$ particles. The $\mathrm{SiC}$ concentration on the surface of Al50Si alloy was calculated by

$$
x_{f}=\frac{W}{\pi r^{2}},
$$

where $x_{f}$ was the $\mathrm{SiC}$ concentration, $W$ was the total amount of $\mathrm{SiC}$ particles in suspension, and $r$ was the radius of the beaker. In this work, $W$ was adjusted to prepare Al50Si alloy sprinkled with $5 \mu \mathrm{m}$ SiC particles at $x_{f}=1 \sim 32 \mathrm{~g} / \mathrm{m}^{2}$. For comparison, Al50Si alloys sprinkled with $1 \mu \mathrm{m} \mathrm{SiC} \mathrm{particles}$ were also prepared at $x_{f}=1 \sim 32 \mathrm{~g} / \mathrm{m}^{2}$.

The brazing process was performed under argon atmosphere. The filler metal was placed between pieces of Al50Si alloys, as shown in Figure 1(b), heated to a predetermined temperature with a heating rate of $20^{\circ} \mathrm{C} \mathrm{min}^{-1}$ and then held for $20 \mathrm{~min}$, allowing the filler metal to reach the semisolid state. While maintaining the temperature, the filler/base metal samples were compressed by an axial pressure of $10 \mathrm{MPa}$ for $15 \mathrm{~min}$ and then cooled in the furnace at a rate of $5^{\circ} \mathrm{C} \mathrm{min}^{-1}$.

The microstructures of the filler metal and the bonded joint were examined using optical microscopy (OM, HIROX200) and scanning electron microscopy (SEM, FEIQuanta 200F) equipped with energy dispersive X-ray spectroscopy (EDS). The elastic modulus of the base metal and filler metal and shear strength of the joint were evaluated on an electromechanical universal testing machine (WDW100). Thermal expansion coefficients of the filler metal and base metal were measured using the dilatometer (DIL, NETZSCH $402 \mathrm{C}$ ) in the temperature range of $20 \sim 100^{\circ} \mathrm{C}$ at a ratio of $5^{\circ} \mathrm{C} \mathrm{min}^{-1}$.

\section{Results and Discussion}

3.1. Confirmation of the Brazing Temperature. Figure 2 shows the effect of temperature on the microstructure of $\mathrm{Zn}$-Al-Cu filler metal. It can be seen that a semisolid microstructure which is composed of globular solid grains and eutectic liquid is obtained after heating. The volume fraction of the globular solid grains constantly decreases with increasing temperature. At $402^{\circ} \mathrm{C}$, they are barely observed compared with that at $382^{\circ} \mathrm{C}$.

The appearance of the globular solid grains is attributed to a process which is called the strain-induced melt activation (SIMA) process. This process is a two-step process consisting of a hot working step and a following semisolid heating step. High internal strain energy is formed in the hot working stage, and then this internal strain energy provides an important driving force for grain spheroidization, helping to transfer the initial gains into spherical grains through grain recrystallization, eutectics melt, liquid penetration, and grain growth in the semisolid heating stage $[10,11]$. In this work, the filler metal has been subjected to severe hot rolling processes before joining. This makes the spheroidization of the solid grains possible at the semisolid brazing temperature.

High volume fraction of solid phases in the filler metal could produce high compression to the base metal and therefore is benefit for the oxide film removal during semisolid compression brazing process [8]. However, fluidity and wetting of the filler metal decreases when filler metal has an excessive solid fraction. In contrast, high liquid phase fraction contributes to the fluidity and wetting of the filler metal, but the compression on base metal dramatically decreases as filler metal has an excessive liquid fraction. In this case, the oxide films are difficult to be broken. Based on the above analysis, the best volume fraction of solid grains is obtained at $392^{\circ} \mathrm{C}$. Therefore, brazing temperature of $392^{\circ} \mathrm{C}$ is selected.

\subsection{Interfacial Microstructure of the Joints. Figure 3 shows} the interfacial microstructure of the joints brazed at $392^{\circ} \mathrm{C}$ with $1 \mu \mathrm{m} \mathrm{SiC} \mathrm{particles.} \mathrm{As} \mathrm{shown} \mathrm{in} \mathrm{Figure} \mathrm{3(a),} \mathrm{when} \mathrm{the}$ concentration of $\mathrm{SiC}$ particles is $1 \mathrm{~g} / \mathrm{m}^{2}$, gaps are observed at the interface, indicating that the oxide film on substrate surface has not been disrupted and bonding is not achieved. As shown in Figure 3(b), when $\mathrm{SiC}$ particle concentration increases to $2 \mathrm{~g} / \mathrm{m}^{2}$, improved bonding is maintained at the interface, where no gaps are observed, except for very small amounts of $\mathrm{SiC}$ particles. At $3 \mathrm{~g} / \mathrm{m}^{2}$, the oxide film has been thoroughly disrupted and increased amount of $\mathrm{SiC}$ particles remain at the interface, forming a thin $\mathrm{SiC}$ particle layer. The filler metal has infiltrated into the clearances between particles and forms a sound bonding with the base metal, as shown in Figure 3(c). The thickness of the $\mathrm{SiC}$ particle layer increases when $\mathrm{SiC}$ concentration is further increased to $4 \mathrm{~g}$ / $\mathrm{m}^{2}$. Small clearances are left among particles, leaving less area available for infiltration of the filler. High-resolution SEM clearly confirms the small clearances where some areas with no signs of bonding are present, as shown in Figure 3(d). 


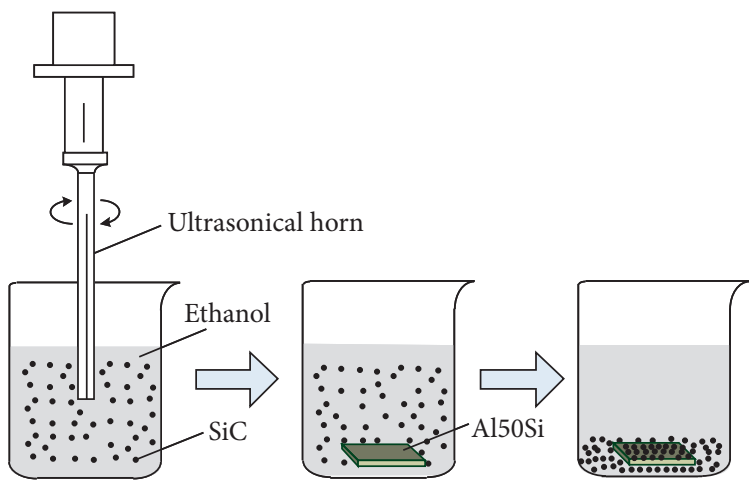

(a)

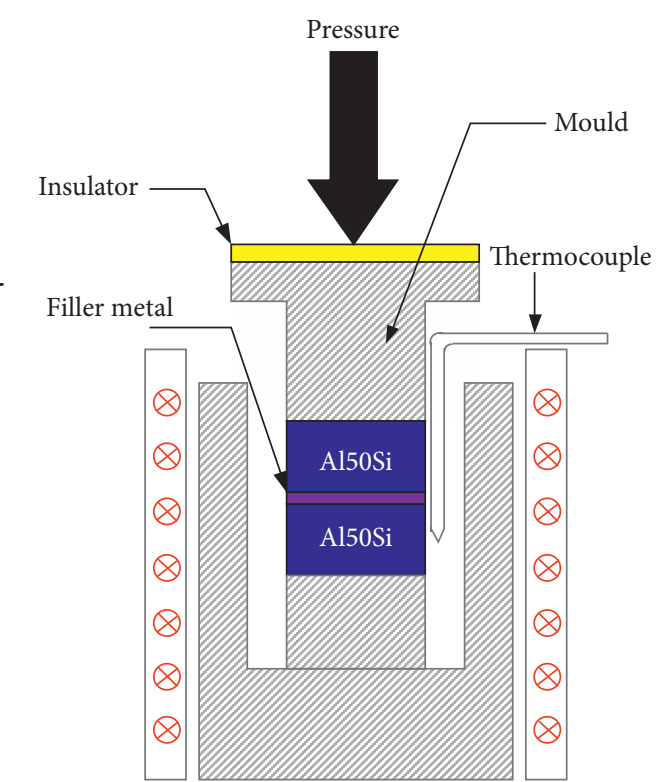

(b)

FIgURE 1: Schematic diagram of (a) suspension sedimentation and (b) semisolid brazing.

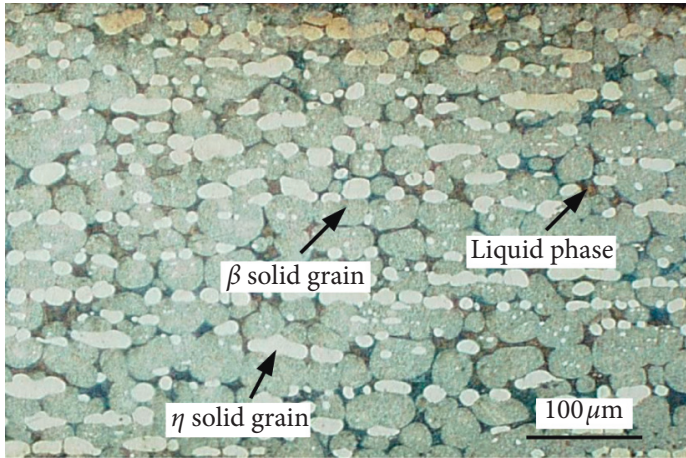

(a)

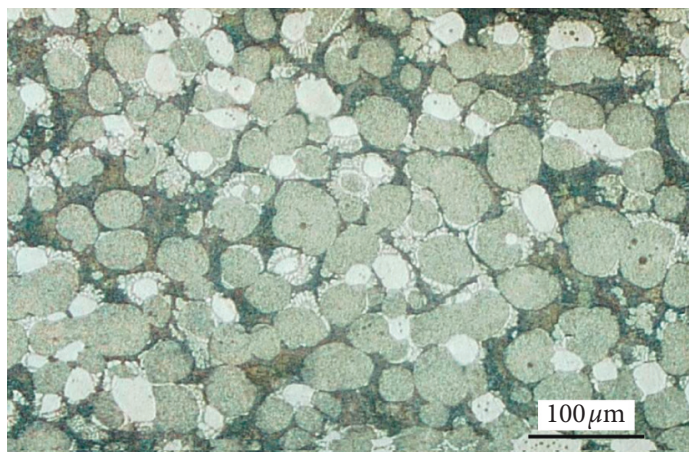

(c)

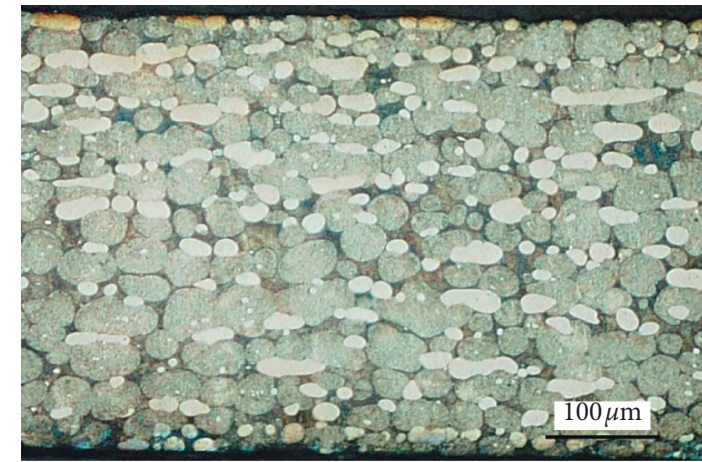

(b)

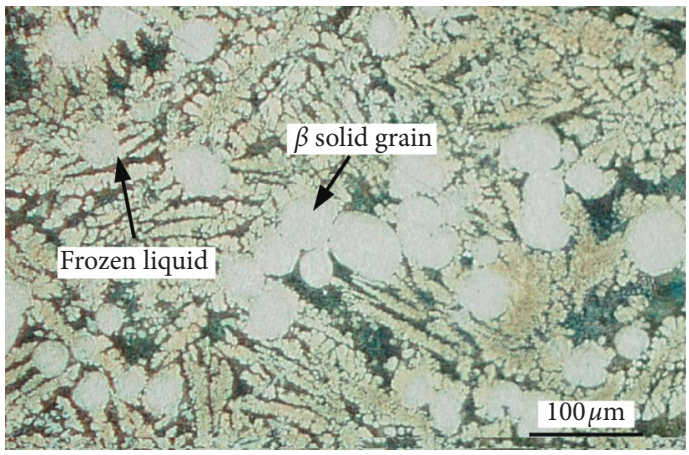

(d)

Figure 2: Microstructure of $\mathrm{Zn}-\mathrm{Al}-\mathrm{Cu}$ filler metal quenching at (a) $382^{\circ} \mathrm{C}$, (b) $386^{\circ} \mathrm{C}$, (c) $392^{\circ} \mathrm{C}$, and (d) $402^{\circ} \mathrm{C}$.

Figure 4 shows the interfacial microstructure of the joints brazed at $392^{\circ} \mathrm{C}$ with $5 \mu \mathrm{m} \mathrm{SiC} \mathrm{particles.} \mathrm{At} 1 \mathrm{~g} / \mathrm{m}^{2}$, the oxide film on substrate surface remains unbroken. A black continuous line which proved to be an oxide layer containing oxide and other impurities can be found at the interface [12], as shown in Figure $4(\mathrm{a})$. At $3 \mathrm{~g} / \mathrm{m}^{2}$, the interface shows very clean area and is free of any black lines, indicating that the oxide film has been disrupted completely (Figure 4(b)). An increased amount of $\mathrm{SiC}$ particles are observed at the interface as $\mathrm{SiC}$ concentration increases to 


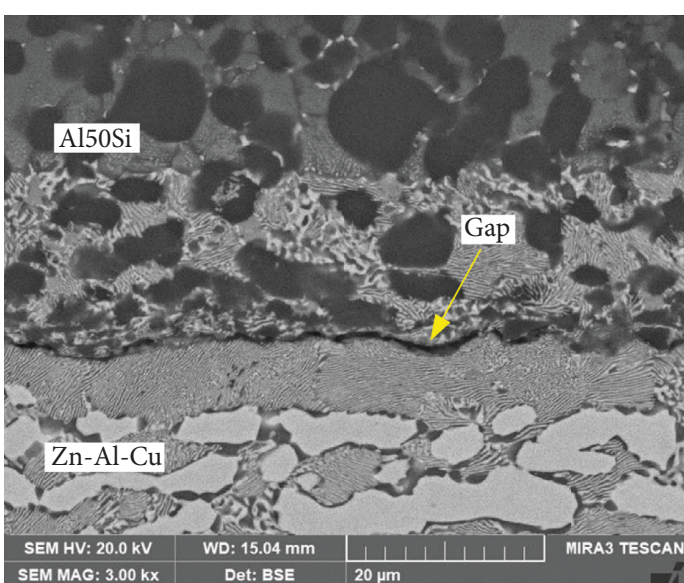

(a)

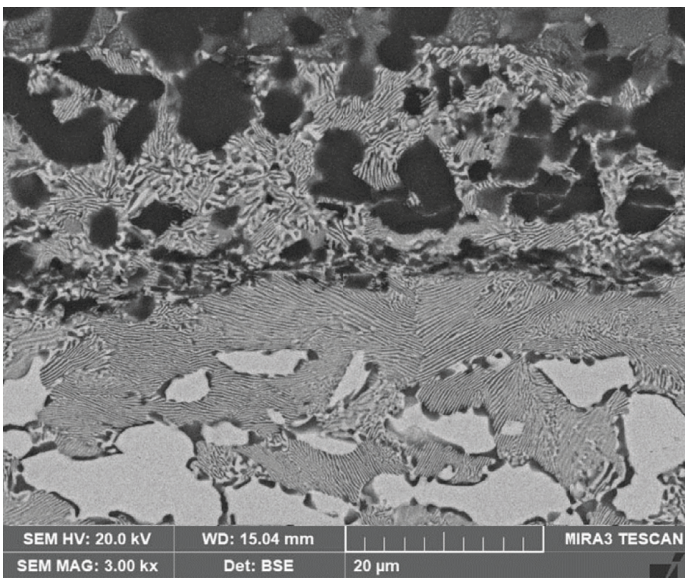

(c)

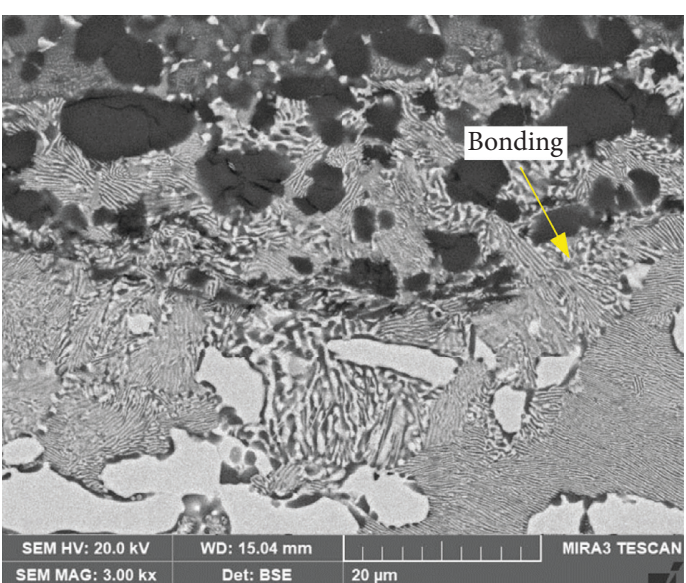

(b)

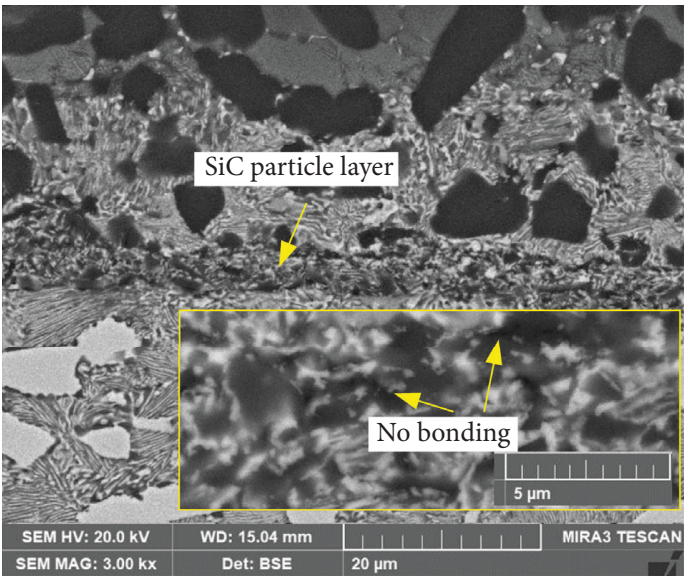

(d)

Figure 3: Interfacial microstructure of the joint with $1 \mu \mathrm{m} \mathrm{SiC} \mathrm{particles} \mathrm{at} \mathrm{(a)} 1 \mathrm{~g} / \mathrm{m}^{2}$, (b) $2 \mathrm{~g} / \mathrm{m}^{2}$, (c) $3 \mathrm{~g} / \mathrm{m}^{2}$, and (d) $4 \mathrm{~g} / \mathrm{m}^{2}$.

$7 \mathrm{~g} / \mathrm{m}^{2}$ and $16 \mathrm{~g} / \mathrm{m}^{2}$ (Figures $4(\mathrm{c})$ and $4(\mathrm{~d})$ ). Moreover, the clearances between the particles are much larger than that in the joint using $1 \mu \mathrm{m} \mathrm{SiC} \mathrm{particles} \mathrm{(Figure} \mathrm{2(d)),} \mathrm{and} \mathrm{good}$ interface bonding is still achieved through the clearances of $\mathrm{SiC}$ particles. When further increasing $\mathrm{SiC}$ concentration to $32 \mathrm{~g} / \mathrm{m}^{2}$, the thickness of the SiC particle layer sharply increases, and nonwetting area is observed in the $\mathrm{SiC}$ particles layer. The microstructure shown in Figure 2(c) indicates that the liquid phase in the filler is limited at $392^{\circ} \mathrm{C}$, and most of the liquid will be squeezed out under applied pressure. Accordingly, the liquid is not sufficient to wet all the particles when the $\mathrm{SiC}$ particle layer is too thick.

Based on the above results, the size of $\mathrm{SiC}$ particle has an important influence on the interface microstructure of the joint and the infiltration of filler metal. For the joint using $1 \mu \mathrm{m} \mathrm{SiC} \mathrm{particles,} \mathrm{colonies} \mathrm{of} \mathrm{SiC} \mathrm{particle} \mathrm{formed} \mathrm{at} \mathrm{the}$ interface at a very low $\mathrm{SiC}$ concentration. The clearances among particles are very small, and thus infiltration of the filler is difficult at lower concentration. When $5 \mu \mathrm{m} \mathrm{SiC}$ particles are used, colonies of SiC particle appear at a high $\mathrm{SiC}$ concentration. The clearances among particles are large enough to provide a highly effective infiltration, and thus good interface bonding is still obtained at higher SiC concentration. Thus, the use of $5 \mu \mathrm{m} \mathrm{SiC} \mathrm{particles} \mathrm{improves} \mathrm{the}$ range of optimum $\mathrm{SiC}$ concentrations to higher values. It is generally accepted that coarse particles produce high clearances between themselves in comparison with fine particles. As shown in Figure 5, there are certain clearances between particles when they are compactly stacked. If the particle radius is $r_{\mathrm{A}}$, the maximum spherical radius that can be accommodated in the clearances is $r_{\mathrm{B}}$, namely, the clearance radius. Obviously, the clearance radius between coarse particles is higher than that between fine particles when stacked in the same way.

Logically, the infiltration of the filler into coarse particles at high $\mathrm{SiC}$ concentration is effective due to the large clearances between particles. In addition, according to the Kozeny-Carman equation [13], the permeability of the fluid in the porous solids can be expressed as

$$
k=\frac{\varphi^{3}}{K_{z} S^{2}(1-\varphi)^{2}},
$$

where $k$ is the permeability, $K_{Z}$ is the Kozeny constant, $S$ is the specific surface area of the solid particle that makes up the porous body, and $\varphi$ is the porosity of the porous media. Apparently, the permeability decreases with increasing specific surface area of particle under the same condition. 


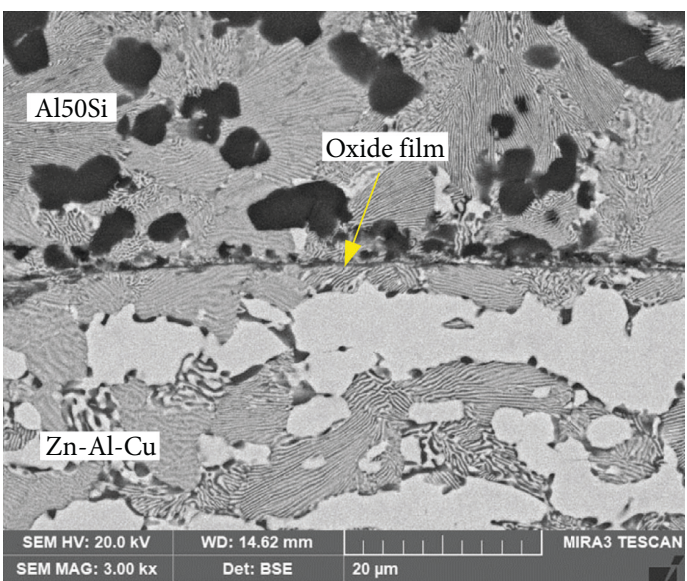

(a)

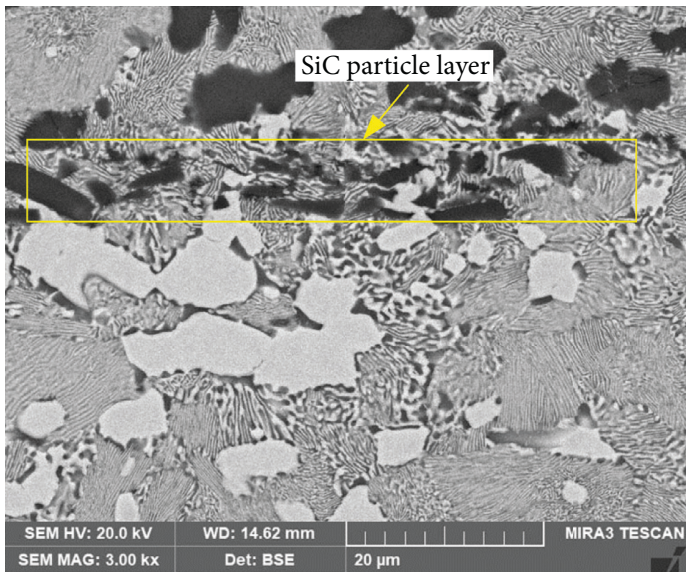

(c)

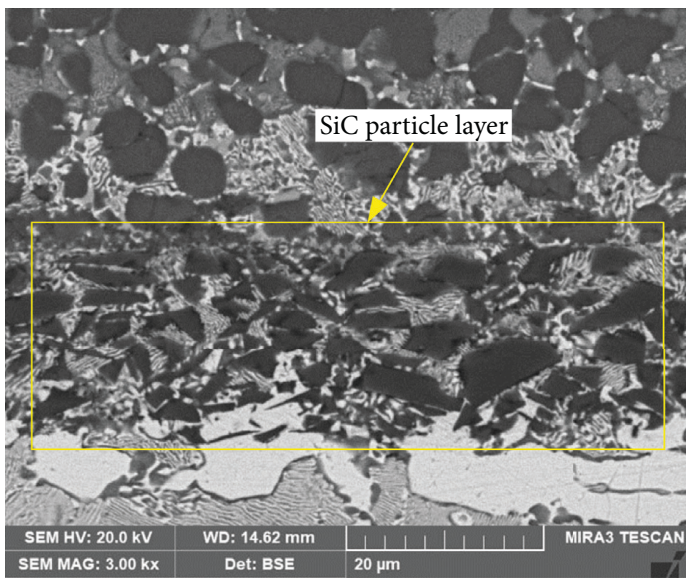

(e)

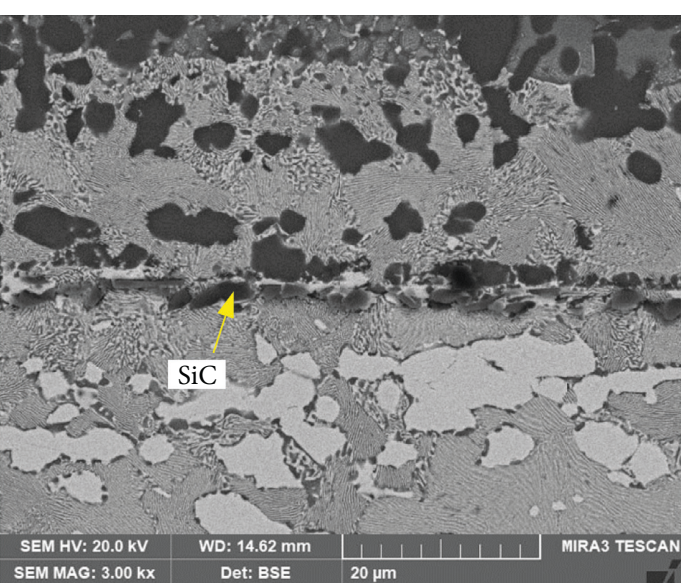

(b)

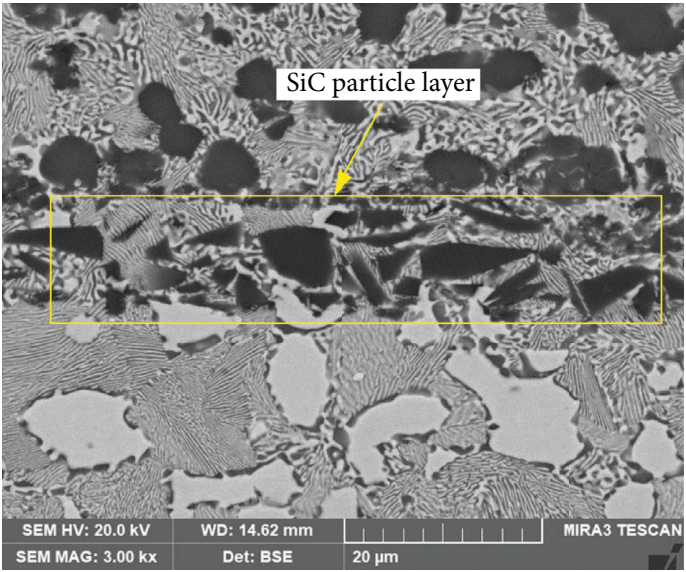

(d)

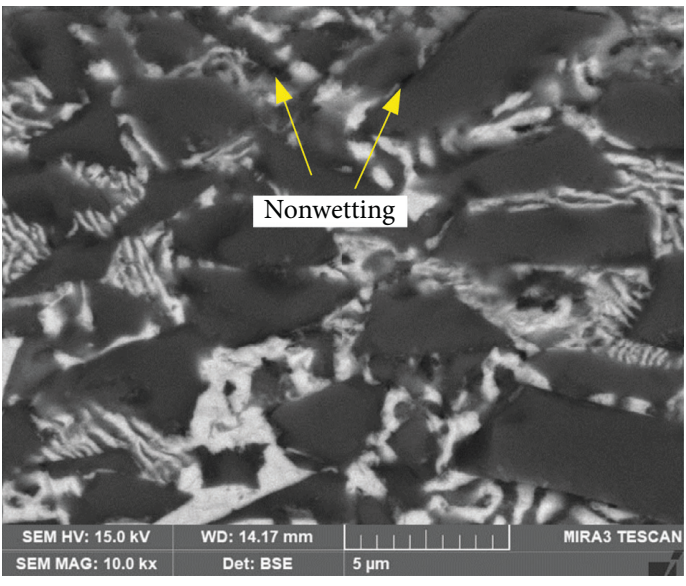

(f)

Figure 4: Interfacial microstructure of the joint with $5 \mu \mathrm{m} \mathrm{SiC} \mathrm{particles} \mathrm{at} \mathrm{(a)} 1 \mathrm{~g} / \mathrm{m}^{2}$, (b) $3 \mathrm{~g} / \mathrm{m}^{2}$, (c) $7 \mathrm{~g} / \mathrm{m}^{2}$, (d) $16 \mathrm{~g} / \mathrm{m}^{2}$, and (e) and (f) $32 \mathrm{~g} / \mathrm{m}^{2}$.

This can be attributed to an interaction between the solid particles and fluid during the permeation process. The influence of this interaction increases with the increase of the specific surface area of particles, resulting in the increase of the resistance to flow and thus the decrease of the permeability. Therefore, fine particles are associated with the low permeability due to their high specific surface area, which induces a high fluid resistance.
The surface oxide film is one of the greatest obstacles to proper interface bonding between the filler and base metal. In our previous works, the semisolid compression brazing has been used to join $\mathrm{SiC}_{\mathrm{p}} / \mathrm{Al}$ composites. The oxide film on the surface of $\mathrm{SiC}_{\mathrm{p}} / \mathrm{Al}$ composites was effectively broken by compression and friction of the solid grains in the semisolid filler under constant pressure [8]. However, the oxide film on the surface of Al50Si alloys cannot be completely 


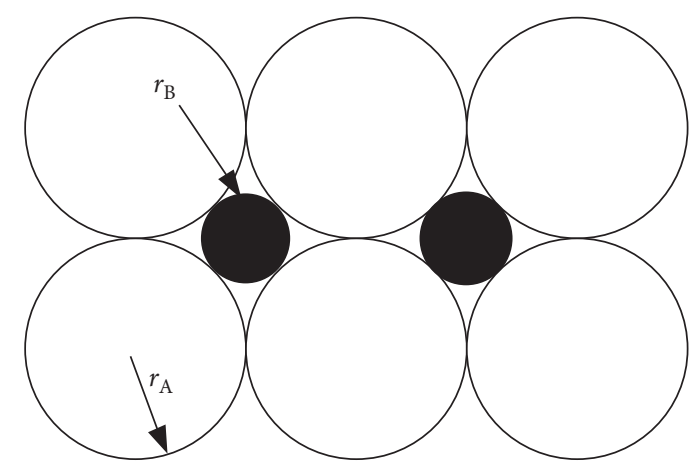

(a)

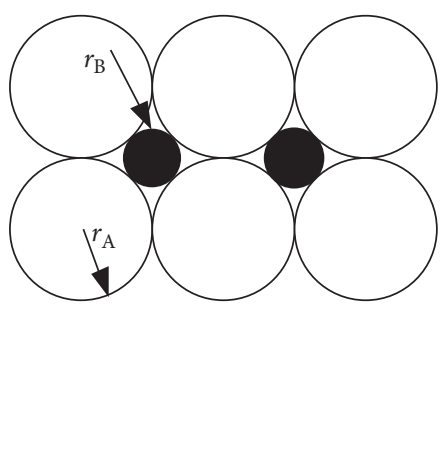

(b)

FIgURE 5: Model of the packed structure of (a) coarse particles and (b) fine particles.

disrupted by these solid grains in this work. As shown in Figures 3(a) and 4(a), continuous oxide film is still present at the interface of the joint when $\mathrm{SiC}$ concentration is lower than $3 \mathrm{~g} / \mathrm{m}^{2}$. Therefore, we believe that both the solid grains in the filler and $\mathrm{SiC}$ particles sprinkled on the base metal surface contribute to the oxide film removal during the SiCassisted semisolid brazing process. Since the filler metal and Al50Si base metal are fixed closely, once pressure is applied, solid grains in the filler and $\mathrm{SiC}$ particles sprinkled on Al50Si surface produce strong compression to the base metal. The compression is so high that microplastic deformation of base metal happens and the continuous oxide film distributed on base metal surface locally cracks due to its poor ductility. Once cracks occur, the filler metal has the chance to diffuse into the base metal, causing the decrease of local melting temperature and partial melting of the diffusion zone. The bonding interface in Figure 3(b) shows that the filler metal has diffused into the base metal before the oxide film is completely destroyed. EDS analysis result shows that the concentration of $\mathrm{Zn}$ and $\mathrm{Cu}$ in the diffusion zone is $47.9 \mathrm{wt} . \%$ and $1.54 \mathrm{wt} . \%$, indicating that the melting point of the diffusion zone is lowered and the partial melting is inevitable. As the base metal melts, the surface oxide films become suspended and easily dispersed into the $\mathrm{SiC}$ particle layer under pressure.

3.3. Mechanical Properties of the Joints. Figure 6 shows the shear strength of the joints at different $\mathrm{SiC}$ concentrations. When $1 \mu \mathrm{m} \mathrm{SiC} \mathrm{particles} \mathrm{are} \mathrm{used,} \mathrm{the} \mathrm{shear} \mathrm{strength} \mathrm{initially}$ increases and then decreases with increasing $\mathrm{SiC}$ concentration, reaching the maximum value at $3 \mathrm{~g} / \mathrm{m}^{2}$, as shown in Figure 6. According to Figure 3, it can be deduced that the increase of the bond joint is associated with the oxide film removal as $\mathrm{SiC}$ concentration increases from $1 \mathrm{~g} / \mathrm{m}^{2}$ to $3 \mathrm{~g} /$ $\mathrm{m}^{2}$. When further increasing $\mathrm{SiC}$ concentration to $4 \mathrm{~g} / \mathrm{m}^{2}$, the presence of nonwetting area in $\mathrm{SiC}$ particles layer results in the decrease in the bond strength.

Figure 7 shows the fracture surface of the joints with $1 \mu \mathrm{m} \mathrm{SiC} \mathrm{particle} \mathrm{at} 1 \mathrm{~g} / \mathrm{m}^{2}, 3 \mathrm{~g} / \mathrm{m}^{2}$, and $4 \mathrm{~g} / \mathrm{m}^{2}$. When $\mathrm{SiC}$ concentration is $1 \mathrm{~g} / \mathrm{m}^{2}$, the fracture occurs along the filler/ base metal interface. A very small amount of $\mathrm{SiC}$ particles and filler metal are observed at the base metal side of the

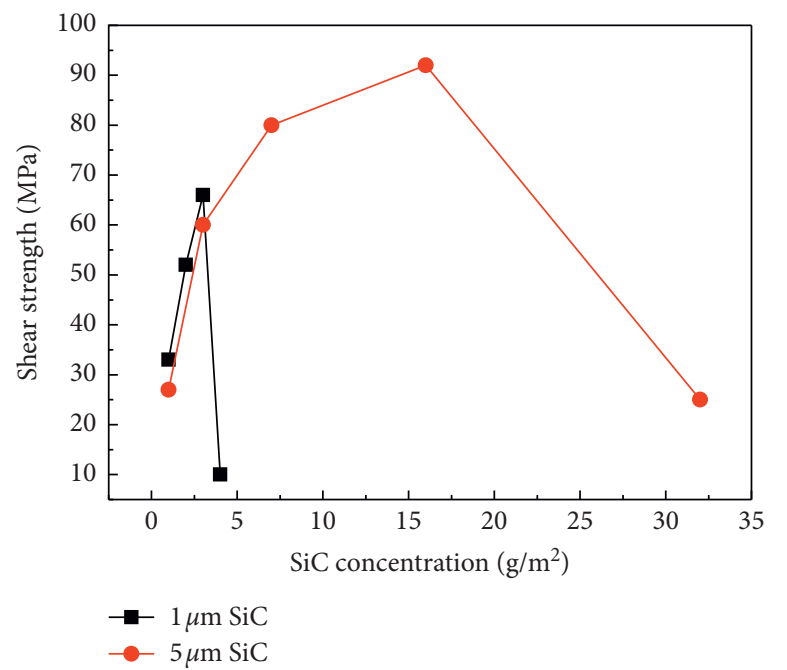

FIgURE 6: Shear strength of the joint at different $\mathrm{SiC}$ concentrations.

fracture surface, indicating that no obvious bonding between the filler and base metal has been obtained (Figures $7(\mathrm{a})$ and $7(\mathrm{~b})$ ). At $3 \mathrm{~g} / \mathrm{m}^{2}$, the fracture also occurs along the filler/base metal interface. In contrast, increased $\mathrm{SiC}$ particles and filler metal were observed at the base side of the fracture surface (Figures $7(\mathrm{c})$ and $7(\mathrm{~d})$ ). This demonstrates that the bonding between the filler and base metal increases after the removal of the oxide film, resulting in the increase of the bond strength. As $\mathrm{SiC}$ concentration increases to $4 \mathrm{~g} / \mathrm{m}^{2}$, both sides of the fracture are characterized by the presence of $\mathrm{SiC}$ particles, implying that the fracture occurs in the $\mathrm{SiC}$ particles layer (Figures $7(\mathrm{e})$ and $7(\mathrm{f})$ ). The nonwetting areas in the $\mathrm{SiC}$ particle layer can be treated as preexisting cracks. These cracks are easy to grow, coalesce, and form the larger cracks under external loads, resulting in the failure of the joint and the decrease in the bond strength.

When $5 \mu \mathrm{m} \mathrm{SiC}$ particles were used, a dramatic increase in the bond strength occurs as the $\mathrm{SiC}$ concentration increases from $1 \mathrm{~g} / \mathrm{m}^{2}$ to $16 \mathrm{~g} / \mathrm{m}^{2}$ and then a decrease in bond strength is obvious as $\mathrm{SiC}$ concentration further increases to $32 \mathrm{~g} / \mathrm{m}^{2}$, as shown in Figure 6. When $\mathrm{SiC}$ concentration 


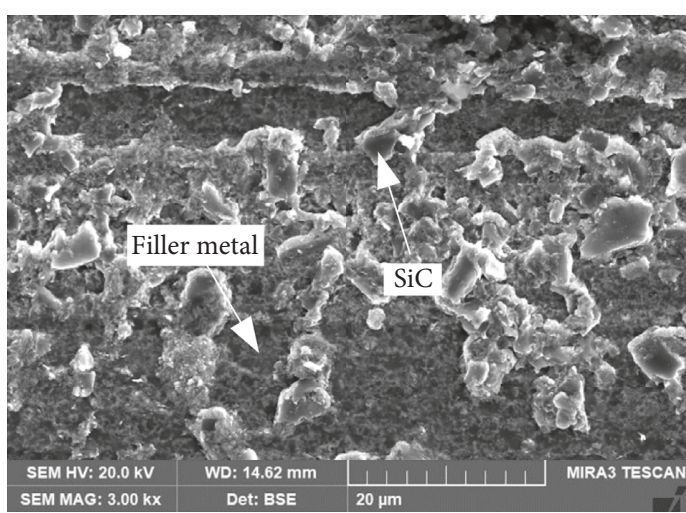

(a)

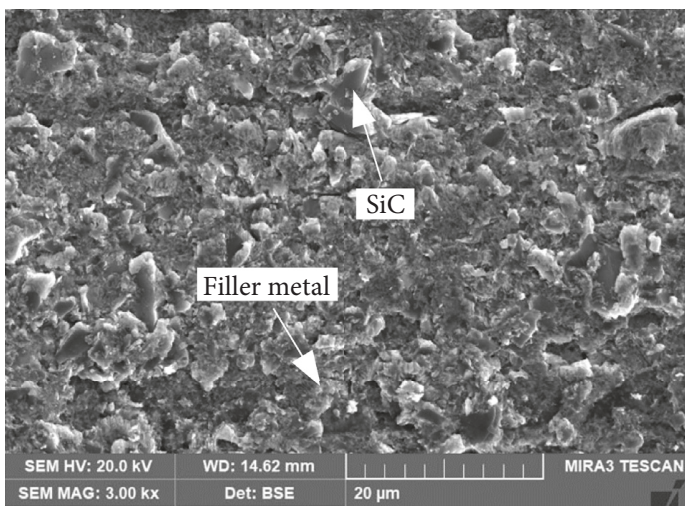

(c)

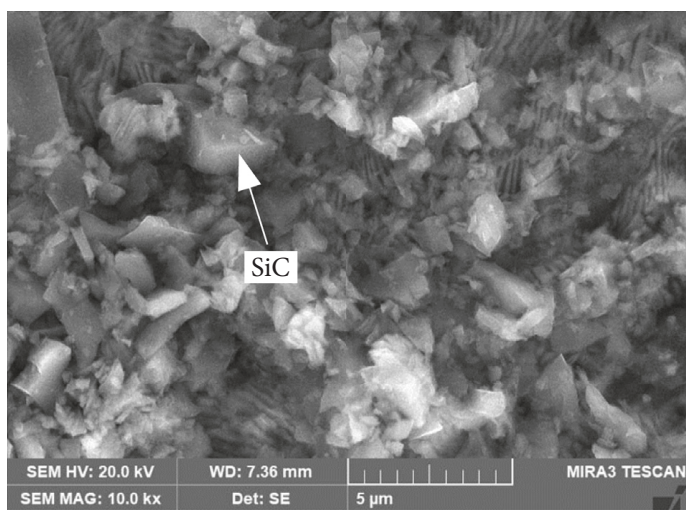

(e)

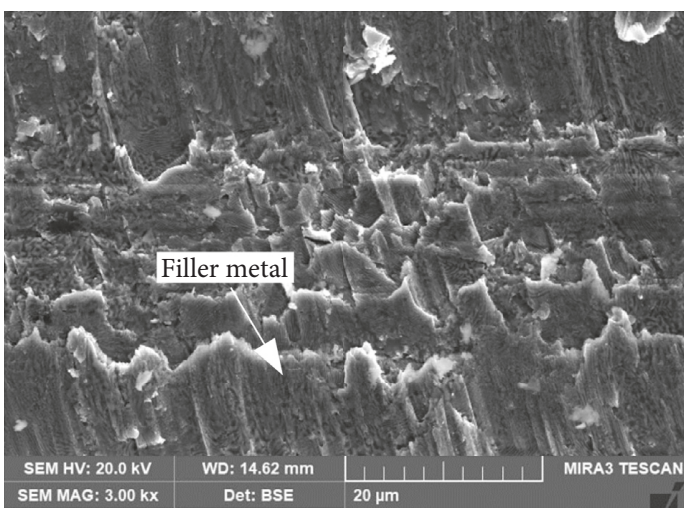

(b)

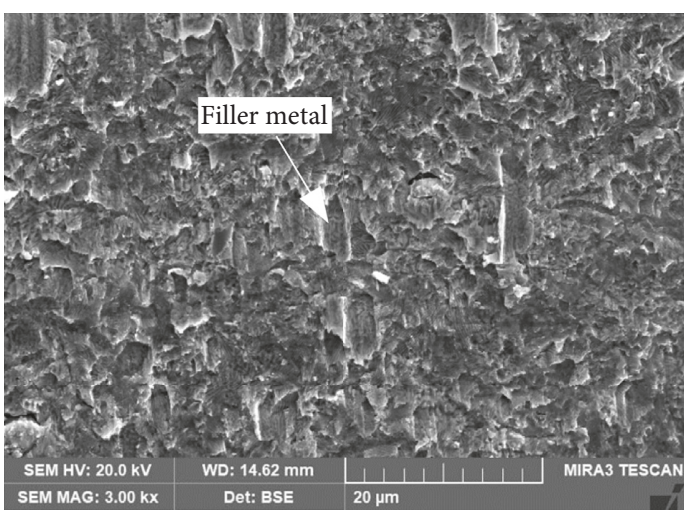

(d)

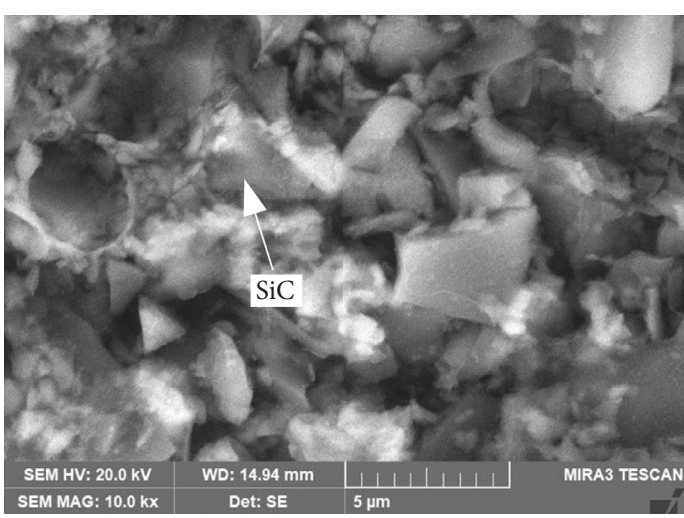

(f)

Figure 7: Fracture surface of the joint with $1 \mu \mathrm{m} \mathrm{SiC} \mathrm{particles} \mathrm{at} \mathrm{(a,} \mathrm{b)} 1 \mathrm{~g} / \mathrm{m}^{2}$, (c, d) $3 \mathrm{~g} / \mathrm{m}^{2}$, and (e, f) $4 \mathrm{~g} / \mathrm{m}^{2}$.

increases from $1 \mathrm{~g} / \mathrm{m}^{2}$ to $3 \mathrm{~g} / \mathrm{m}^{2}$, the removal of the oxide film at the interface contributes to the increase in the bond strength, which is similar with that in the joint using $1 \mu \mathrm{m}$ $\mathrm{SiC}$ particles. However, when $\mathrm{SiC}$ concentration increases to $16 \mathrm{~g} / \mathrm{m}^{2}$, increased $\mathrm{SiC}$ volume fraction in the $\mathrm{SiC}$ particle layer is responsible for the increased bonding strength. To explain this result, the fracture path and fracture surface of the joints with $5 \mu \mathrm{m} \mathrm{SiC} \mathrm{particles} \mathrm{at} 3 \mathrm{~g} / \mathrm{m}^{2}$ and $16 \mathrm{~g} / \mathrm{m}^{2}$ are observed. As shown in Figures 8(a) and 8(c), both of the fractures occur along the filler/SiC particles layer interface. The base side of the fracture surface is characterized by many $\mathrm{SiC}$ particles and filler metal between them (Figures $8(\mathrm{~b})$ and $8(d))$. According to the physical properties of materials, both of the fractures may be caused by differences between the thermal expansion coefficient of the filler metal and $\mathrm{SiC}$ particle layer. Researchers $[14,15]$ found that large residual stress can easily be produced in the joint when brazing of two dissimilar materials with large mismatch of the thermal expansion coefficients. The residual stress causes the generation of the crack at the interface between the dissimilar materials under external mechanical loads, resulting in the failure of the whole joint.

Thermal expansion coefficients of $\mathrm{Zn}$-Al-Cu filler metal and Al50Si base metal in this work, determined experimentally, are $23 \times 10^{-6} \mathrm{~K}^{-1}$ and $11 \times 10^{-6} \mathrm{~K}^{-1}$, respectively (Table 1). The $\mathrm{SiC}$ particle layer appears as a composite 


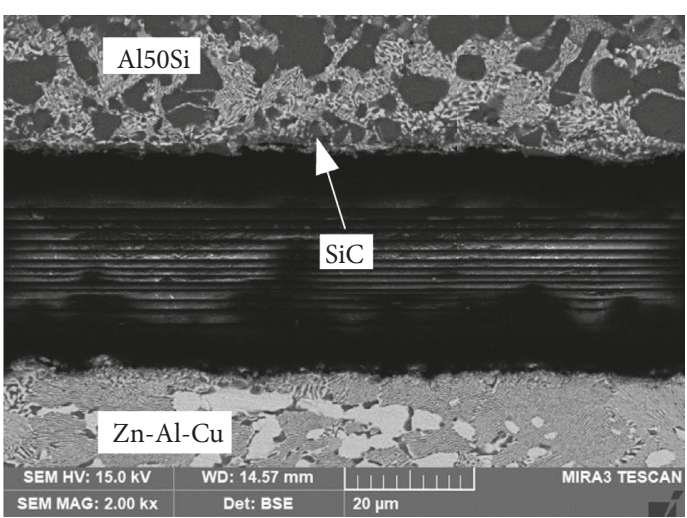

(a)

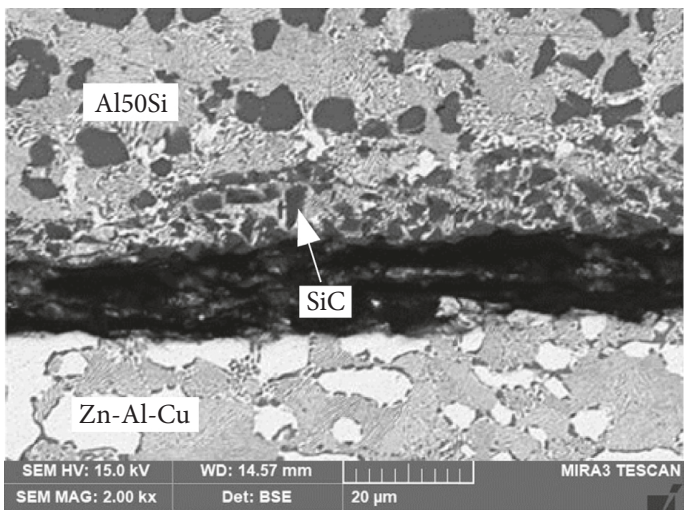

(c)

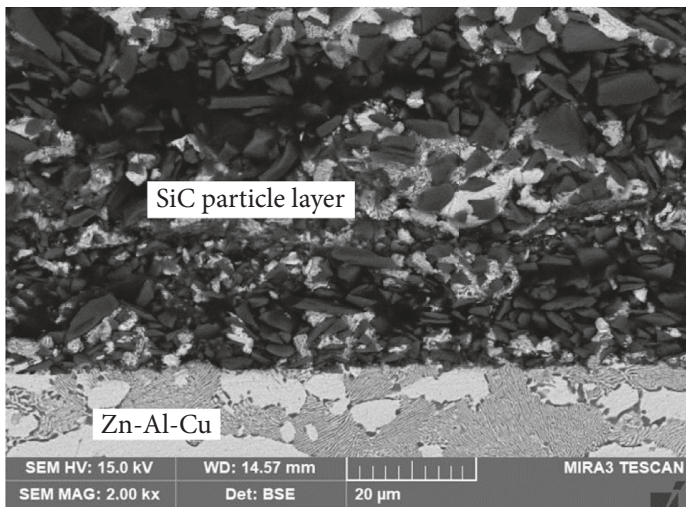

(e)

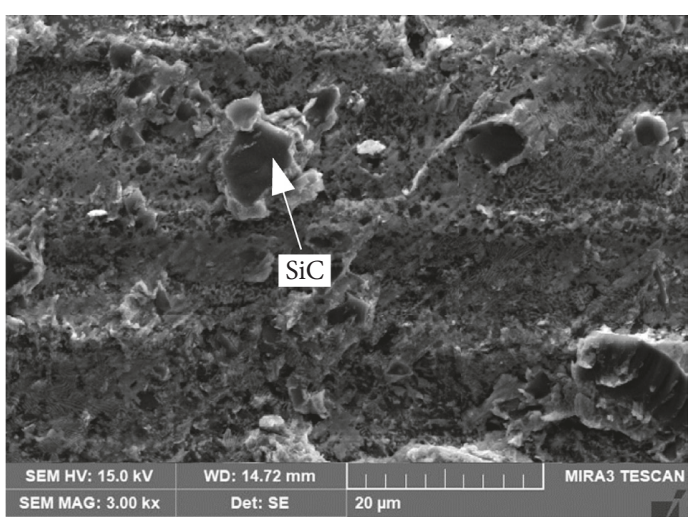

(b)

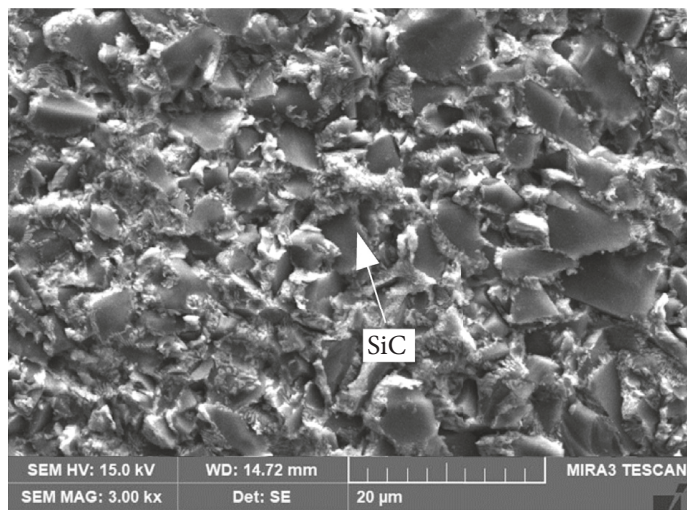

(d)

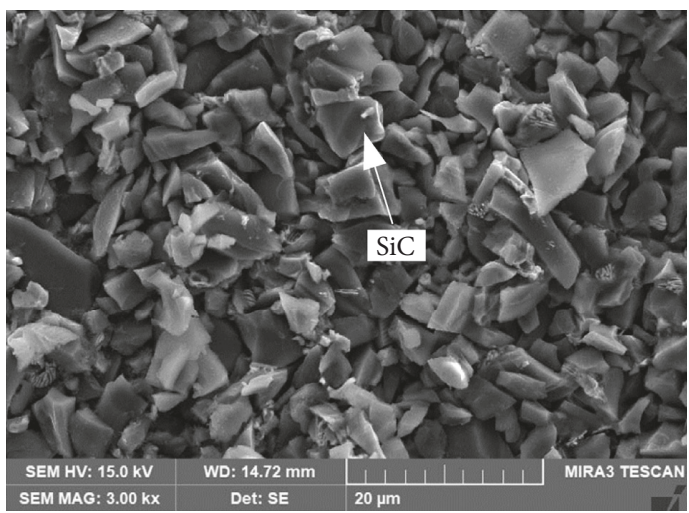

(f)

FIGURE 8: Fracture path and fracture surface of the joint with $1 \mu \mathrm{m} \mathrm{SiC} \mathrm{particles} \mathrm{at} \mathrm{(a)} \mathrm{and} \mathrm{(b)} 3 \mathrm{~g} / \mathrm{m}^{2}$, (c) and (d) $16 \mathrm{~g} / \mathrm{m}^{2},(\mathrm{e})$ and (f) $32 \mathrm{~g} / \mathrm{m}^{2}$.

composed of $\mathrm{SiC}$ particles and $\mathrm{Zn}-\mathrm{Al}-\mathrm{Cu}$ filler metal. Therefore, thermal expansion coefficient of the SiC particle layer can be calculated using Turner's model [16], which is a theoretical model for predicting the thermal expansion coefficient of composite materials:

$$
\alpha_{c}=\frac{\alpha_{p} V_{p} K_{p}+\alpha_{m} V_{m} K_{m}}{V_{p} K_{p}+V_{m} K_{m}},
$$

where $\alpha_{c}, \alpha_{m}$, and $\alpha_{p}$ are the thermal expansion coefficients of the $\mathrm{SiC}$ particle layer, $\mathrm{Zn}$-Al-Cu filler metal, and $\mathrm{SiC}$ particles, respectively. $V_{m}$ and $V_{p}$ are the volume fraction of $\mathrm{Zn}-\mathrm{Al}-\mathrm{Cu}$ filler metal and $\mathrm{SiC}$ particles in the $\mathrm{SiC}$ particle layer, respectively. $K_{m}$ and $K_{p}$ are the bulk modulus of $\mathrm{Zn}$-Al-Cu filler metal and $\mathrm{SiC}$ particles. The relationship between bulk modulus $K$ and elastic modulus $E$ and Poisson's ratio $v$ can be expressed as follows [16]:

$$
K=\frac{E}{3(1-2 v)} .
$$

The volume fraction of $\mathrm{SiC}$ particles in $\mathrm{SiC}$ particle layers is measured by Leica Q550MW phase analysis software. The main physical properties of $\mathrm{SiC}$ particles [17] and $\mathrm{Zn}-\mathrm{Al}-\mathrm{Cu}$ filler metal determined experimentally are shown in Table 1.

It is calculated that the thermal expansion coefficients of the SiC particle layer are $15 \times 10^{-6} \mathrm{~K}^{-1}$ and $10 \times 10^{-6} \mathrm{~K}^{-1}$ when $\mathrm{SiC}$ concentration is $3 \mathrm{~g} / \mathrm{m}^{2}$ and $16 \mathrm{~g} / \mathrm{m}^{2}$, both close to 
TABle 1: Physical properties of SiC particles, $\mathrm{Zn}-\mathrm{Al}-\mathrm{Cu}$ filler metal, and Al50Si base metal.

\begin{tabular}{lccc}
\hline Material & Elastic modulus $(\mathrm{GPa})$ & Thermal expansion coefficient $\left(10^{-6} \cdot \mathrm{K}^{-1}\right)$ & Poisson's ratio \\
\hline $\mathrm{SiC}$ & 460 & 4.5 & 0.17 \\
$\mathrm{Zn}-\mathrm{Al}-\mathrm{Cu}$ filler & 93 & 23 & 0.33 \\
Al50Si base metal & 121 & 11 & - \\
\hline
\end{tabular}

that of the base metal and different from that of the filler metal. Thus, high thermal stress will inevitably develop at the $\mathrm{SiC}$ particle layer/filler metal interface on cooling of the joint, as a result of the thermal expansion mismatch between $\mathrm{SiC}$ particle layer and filler metal. Some of the thermal stresses are alleviated through yielding of the filler metal. As a result, new dislocations are generated at the $\mathrm{SiC}$ particle layer/filler metal interface [18], leading to the high interface strengthening effect. However, some of the thermal stress could not be alleviated. In this case, residual stress forms at the $\mathrm{SiC}$ particle layer/filler metal interface, causing the failure of the joint under external loads [19], as shown in Figures 8(a) and 8(c). According to the analysis software measurement results, $\mathrm{SiC}$ volume fraction in the $\mathrm{SiC}$ particle layer increases as $\mathrm{SiC}$ concentration increases from $3 \mathrm{~g} / \mathrm{m}^{2}$ to $16 \mathrm{~g} / \mathrm{m}^{2}$. Therefore, increased dislocation densities will be generated at the $\mathrm{SiC}$ particle layer/filler metal interface because of the hindering of $\mathrm{SiC}$ during yielding of filler metal. As a result, increased dislocation strengthening effect and bond strength are obtained with increasing $\mathrm{SiC}$ concentration. When $\mathrm{SiC}$ concentration further increases to $32 \mathrm{~g} / \mathrm{m}^{2}$, the fracture occurs in the $\mathrm{SiC}$ particles layer (Figure 8(e)), and a large number of $\mathrm{SiC}$ particles with less filler metal between them are observed at the fracture surface (Figure 8(f)), indicating that the large nonwetting area in the $\mathrm{SiC}$ particle layer is responsible for the fracture of the joint and the low bond strength.

\section{Conclusions}

A new semisolid compression brazing of Al50Si alloy using $\mathrm{Zn}-\mathrm{Al}-\mathrm{Cu}$ filler metal assisted by $\mathrm{SiC}$ particles has been successfully developed. The surface oxide film can be effectively disrupted, and high strength bonds are obtained at the optimum $\mathrm{SiC}$ concentration.

(1) For $1 \mu \mathrm{m} \mathrm{SiC} \mathrm{particles,} \mathrm{the} \mathrm{oxide} \mathrm{film} \mathrm{on} \mathrm{the} \mathrm{surface}$ of the base metal is completely disrupted as $\mathrm{SiC}$ particles concentration increases to $3 \mathrm{~g} / \mathrm{m}^{2}$, resulting in a good bonding strength. As $\mathrm{SiC}$ concentration further increases to $4 \mathrm{~g} / \mathrm{m}^{2}$, colonies of $\mathrm{SiC}$ particles formed at the interface of the joint and the clearances among particles were very small. In this case, the infiltration of the filler is difficult and the bond strength begins to decrease.

(2) For $5 \mu \mathrm{m} \mathrm{SiC} \mathrm{particles,} \mathrm{obvious} \mathrm{differences} \mathrm{in} \mathrm{mi-}$ crostructure of the joint and infiltration of the filler metal at the joint interface are observed. $\mathrm{SiC}$ colonies form at a high $\mathrm{SiC}$ concentration. The clearances among particles are large enough to provide a highly effective infiltration of the filler metal, and thus good interface bonding is still obtained at the high $\mathrm{SiC}$ concentration. Thus, the use of $5 \mu \mathrm{m} \mathrm{SiC} \mathrm{particles}$ improves the range of optimum $\mathrm{SiC}$ concentrations to higher values.

(3) By using $5 \mu \mathrm{m} \mathrm{SiC} \mathrm{particles,} \mathrm{the} \mathrm{bonding} \mathrm{strength}$ increases due to the removal of the oxide film when $\mathrm{SiC}$ concentration increases from $1 \mathrm{~g} / \mathrm{m}^{2}$ to $3 \mathrm{~g} / \mathrm{m}^{2}$. With increasing $\mathrm{SiC}$ concentration to $16 \mathrm{~g} / \mathrm{m}^{2}$, the bonding strength continues to increase. The dislocation strengthening effect at the $\mathrm{SiC}$ particle layer/ filler metal is responsible for the increased bonding strength, which is caused by the differences in thermal expansion coefficient between SiC particle layer and filler metal. When $\mathrm{SiC}$ concentration further increases to $32 \mathrm{~g} / \mathrm{m}^{2}$, nonwetting area appears inside the SiC particles layer, causing a decrease in the bonding strength.

\section{Data Availability}

All data supporting the findings of this study are reliable and available within the article.

\section{Conflicts of Interest}

The authors declare that they have no conflicts of interest.

\section{Acknowledgments}

This project was supported by the National Natural Science Foundation of China (no. 51802345).

\section{References}

[1] S. P. Hu, C. N. Niu, H. Bian, X. G. Song, J. Cao, and D. Y. Tang, "Surface-activation assisted brazing of $\mathrm{Al}-\mathrm{Zn}-\mathrm{Mg}-\mathrm{Cu}$ alloy: improvement in microstructure and mechanical properties," Materials Letters, vol. 218, pp. 86-89, 2018.

[2] M. Fang, L. Hu, L. Yang, C.-D. Shi, Y.-C. Wu, and W.-M. Tang, "Electroless plating and growth kinetics of Ni-P alloy film on SiCp/Al composite with high $\mathrm{SiC}$ volume fraction," Transactions of Nonferrous Metals Society of China, vol. 26, no. 3, pp. 799-805, 2016.

[3] W. Cui, S. Li, J. Yan, and X. Zhang, "Microstructure and mechanical performance of composite joints of sapphire by ultrasonic-assisted brazing," Journal of Materials Processing Technology, vol. 257, pp. 1-6, 2018.

[4] L. Shi, J. Yan, Y. Han, and B. Peng, "Behaviors of oxide layer at interface between semi-solid filler metal and aluminum matrix composites during vibration," Journal of Materials Science \& Technology, vol. 27, no. 8, pp. 746-752, 2011.

[5] L. Shi, J. Yan, B. Peng, and Y. Han, "Deformation behavior of semi-solid Zn-Al alloy filler metal during compression," Materials Science and Engineering: A, vol. 528, no. 22-23, pp. 7084-7092, 2011. 
[6] H. B. Xu, Q. X. Xing, Y. L. Zeng, Y. Luo, and C. H. Du, "Semisolid stirring brazing of SiCp/A356 composites with Zn27Al filler metal in air," Science and Technology of Welding and Joining, vol. 16, no. 6, pp. 483-487, 2011.

[7] H. Xu, B. Zhou, C. Du, Q. Luo, and H. Chen, "Microstructure and properties of joint interface of semisolid stirring brazing of composites," Journal of Materials Science \& Technology, vol. 28, no. 12, pp. 1163-1168, 2012.

[8] J. Xiao, S. Li, S. Bai, J. Yan, and D. Xiong, "Behaviors of oxide film during semisolid brazing of SiCp/6063Al composite materials," Advances in Materials Science and Engineering, vol. 2018, Article ID 3246371, 11 pages, 2018.

[9] S.-G. Hashemabada, Z.-Y. Gu, and T. Andoa, "Flux-less direct soldering of aluminum by ultrasonic surface activation," Journal of Materials Processing Technology, vol. 233, pp. 135-141, 2016.

[10] B. Behzad and A.-K. Mehrdad, "Phase evolution and mechanical behavior of the semi-solid SIMA processed 7075 aluminum alloy," Metals, vol. 6, no. 3, p. 42, 2016.

[11] C.-W. Lin, F.-Y. Hung, and T.-S. Lui, "High-temperature compressive resistance and mechanical properties improvement of strain-induced melt activation-processed Al-Mg-Si aluminum alloy," Metals, vol. 6, no. 8, p. 183, 2016.

[12] Z. Xu, L. Ma, J. Yan, S. Yang, and S. Du, "Wetting and oxidation during ultrasonic soldering of an alumina reinforced aluminum-copper-magnesium (2024 Al) matrix composite," Composites Part A: Applied Science and Manufacturing, vol. 43, no. 3, pp. 407-414, 2012.

[13] W. D. Carrier, "Goodbye, Hazen; Hello, Kozeny-Carman," Journal of Geotechnical and Geoenvironmental Engineering, vol. 129, no. 11, pp. 1054-1056, 2003.

[14] W. Wang, Y. Wang, J. Huang et al., "Joining of high thermalexpansion mismatched C-SiC composite and stainless steel by an $\mathrm{Ag}+\mathrm{Ti}+\mathrm{Mo}$ mixed powder filler," Materials Letters, vol. 256, p. 126632, 2019.

[15] X. Chen, J. Yan, S. Ren, J. Wei, and Q. Wang, "Ultrasonicassisted brazing of $\mathrm{SiC}$ ceramic to Ti-6Al-4V alloy using a novel AlSnSiZnMg filler metal," Materials Letters, vol. 105, pp. 120-123, 2013.

[16] P. S. Turner, "Thermal-expansion stresses in reinforced plastics," Journal of Research of the National Bureau of Standards, vol. 37, no. 4, pp. 239-250, 1946.

[17] W. Zheng, X. He, M. Wu et al., “Thermal expansion coefficient of Diamond/SiC composites prepared by silicon vapor infiltration in vacuum," Vacuum, vol. 159, pp. 507-515, 2019.

[18] R. J. Arsenault and N. Shi, "Dislocation generation due to differences between the coefficients of thermal expansion," Materials Science and Engineering, vol. 81, pp. 175-187, 1986.

[19] E. S. Folias, M. Hohn, and T. Nicholas, "Predicting crack initiation in composite material systems due to a thermal expansion mismatch," International Journal of Fracture, vol. 93, no. 1/4, pp. 335-349, 1998. 


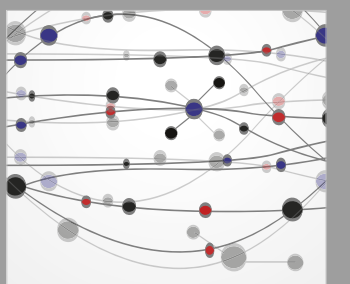

The Scientific World Journal
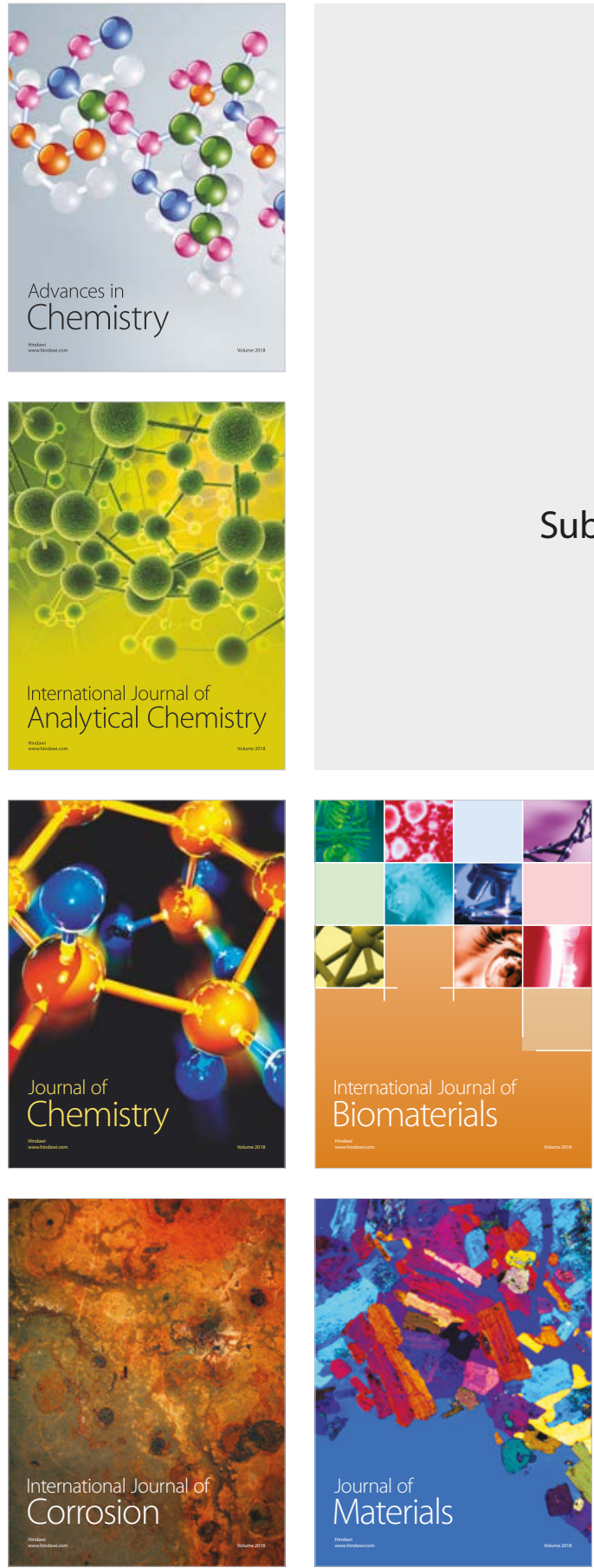

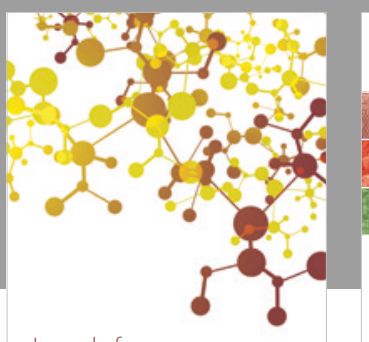

Journal of

Applied Chemistry
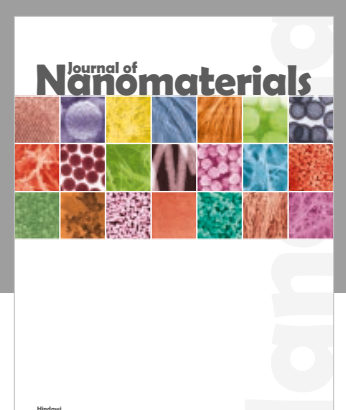

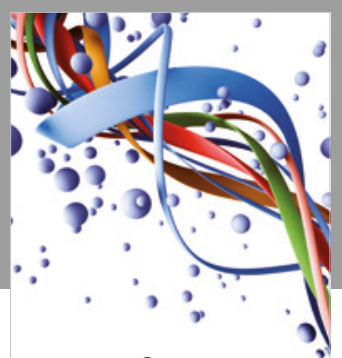

Scientifica

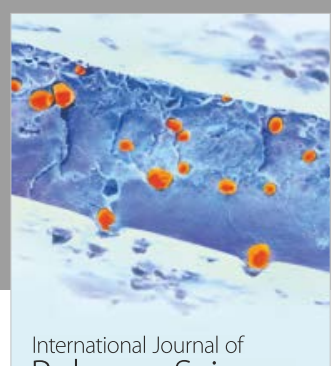

Polymer Science

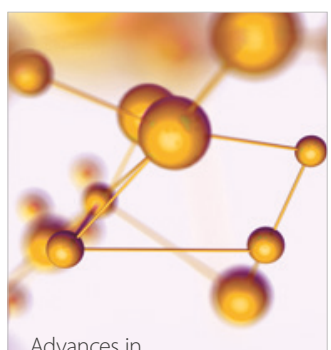

Physical Chemistry
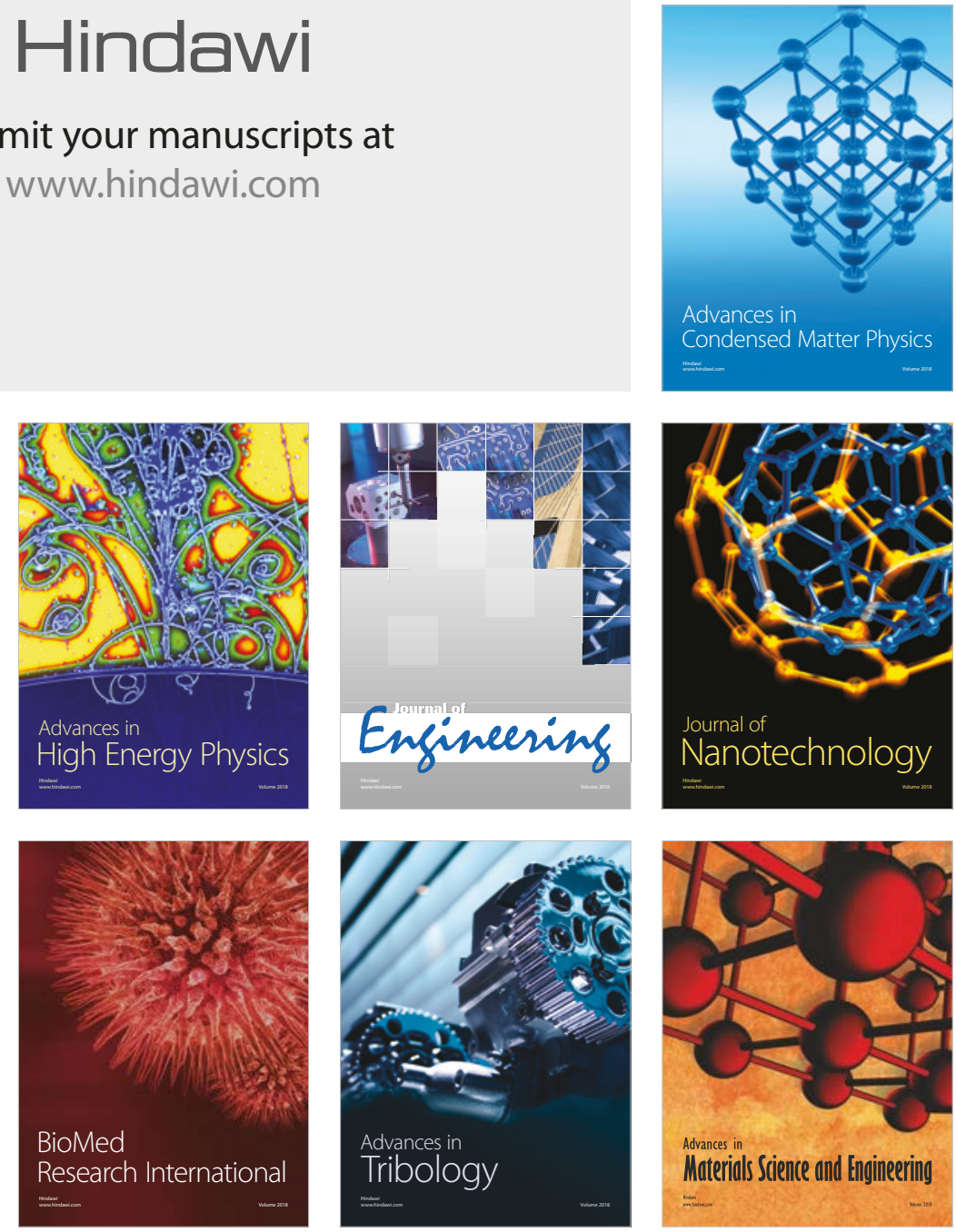